\title{
Proposal for a reliable enterococcal cytolysin production assay avoiding apparent incongruence between phenotype and genotype
}

Enterococci are Gram-positive lactic acid bacteria which have been known since the end of the 19th century to be associated with humans both as natural colonizers and as infectious agents. At the beginning of the 20th century, these bacteria were also recognized as being able to clot milk. The relevance and the importance of these bacteria are concerned mostly with two particular aspects, which have certainly generated discussion among researchers and have encouraged them to clarify the virulence mechanisms involved in the pathogenesis of infections caused by enterococci. Firstly, enterococci are human commensals that are used in the production of some fermented foods, but are also important nosocomial pathogens. Secondly, their virulence is still debated and puzzling, not only because both infectious and non-infectious strains carry the same putative virulence traits, but also because the bacterial factors mediating virulence may be diverse between different strains and species (Bourgogne et al., 2008).

The cytolysin (haemolysin/bacteriocin) system is one of the best studied virulence traits in Enterococcus. It is encoded by an operon beginning with the $c y l L_{\mathrm{L}}$ gene and ending at the cyll gene (Fig. 1). This cytolysin contributes to virulence in infection models (Clewell, 2007). It is therefore important, for enterococcal isolates from both clinical specimens and food sources, to screen for the production and genetic carriage of this virulence factor. Although several phenotypic techniques for the detection of haemolytic activity have been described (Park et al., 2007), the gold standard method for the production of haemolysin has been for a long time the presence or absence of clear zones ( $\beta$-haemolysis) surrounding colonies on blood agar plates (Balashova et al., 2006). This method, however, is influenced by factors such as medium composition, the species of red blood cells used, the presence of oxygen and the duration of incubation. In fact, no single standardized method has been described.

The fact that eight described cytolysin genes are considered essential for the production of a functional cytolysin makes the screening for both divergent operons of the $c y l$ locus important (Fig. 1). The screening for a single gene or part, or parts, of the entire cytolysin determinant will only indicate a strain's potential for production of the haemolysin/bacteriocin activity.

\section{A thorough search in the literature} revealed that not only are the phenotypic assays not performed under the same conditions, but also that, in the majority of the experiments, only a few $c y l$ genes are screened for, often leading to incongruent results between the genotype and phenotype of strains (Shepard \& Gilmore, 2002; Creti et al., 2004; Seno et al., 2005;

McBride et al., 2007; and further references therein). Such apparent incongruence needs to be resolved in order to clearly determine whether experimental design accounts for these or whether phenotypic expression of haemolysin/bacteriocin is lacking where the genotypic potential for cytolysin production exists. We believe that unambiguous procedures for both the genetic and the phenotypic screening of enterococcal isolates are essential and should be the starting point for clarifying the apparent incongruence suggested by the literature.

Knowing that cytolysin is produced by a complex process that requires the products of eight genes, a primer pair was designed (Fig. 1) based on the sequence of the cytolysin locus of Enterococcus faecalis strain MMH594 from the $c y l R 2$ gene to the cylI gene (GenBank accession no. AY032999). In this manner, the two divergent operons of the cytolysin locus were amplified, enabling a genotypic screening that would represent the complete $c y l$ locus (Cf, GGT TGC CAT TGA AAA ATA TCT TCT AGT GGA GTA TCC AGG, from bp 194 to 156 of the cylR2 gene; Cr, GTG ATT GAT TGG CTT ATT TCA TCA TCA TCA CTT TTG AGC, from bp 902 to 863 of the cyll gene). The PCR was performed using an Expand Long Template PCR system (Roche) and the conditions recommended by the manufacturer. The thermal cycling parameters for the 8364 bp PCR product consisted of one cycle at $94{ }^{\circ} \mathrm{C}$ for $2 \mathrm{~min}$ and 10 cycles at $94{ }^{\circ} \mathrm{C}$ for $10 \mathrm{~s}, 50{ }^{\circ} \mathrm{C}$ for $30 \mathrm{~s}$, and $68{ }^{\circ} \mathrm{C}$ for $10 \mathrm{~min}$. This was followed by 20 cycles at $94{ }^{\circ} \mathrm{C}$ for $10 \mathrm{~s}$, $50{ }^{\circ} \mathrm{C}$ for $30 \mathrm{~s}$, and $68{ }^{\circ} \mathrm{C}$ for $10 \mathrm{~min}$ (with the elongation time increasing by $10 \mathrm{~s}$ per cycle) and a final cycle at $68{ }^{\circ} \mathrm{C}$ for $7 \mathrm{~min}$. The PCR screening for the complete $c y l$ locus was performed on 55 strains from nosocomial infections and from food (milk and cheese): 36 E. faecalis, 7 Enterococcus faecium, 4 Enterococcus hirae and 8 Enterococcus durans.

The phenotypic screening of the enterococcal strains for cytolysin production was performed on Columbia blood agar supplemented with $5 \%(\mathrm{v} / \mathrm{v})$ horse blood (Becton Dickinson) and incubated at $37{ }^{\circ} \mathrm{C}$ for 24 or $48 \mathrm{~h}$, under anaerobic conditions (GasPak EZ Gas Generating Container Systems; Becton Dickinson).

The results are presented in Table 1. No differences in haemolytic activity were seen between the durations of incubation (24 and $48 \mathrm{~h}$ ) at $37{ }^{\circ} \mathrm{C}$. All strains were also tested on BHI agar supplemented with $5 \%$ (v/v) human blood, incubated at $37{ }^{\circ} \mathrm{C}$ for 24 or $48 \mathrm{~h}$ under identical anaerobic conditions. No differences were seen between the results obtained for blood plates with human or horse erythrocytes. Nonetheless, the haemolytic clearing zones were more evident on horse blood (data 


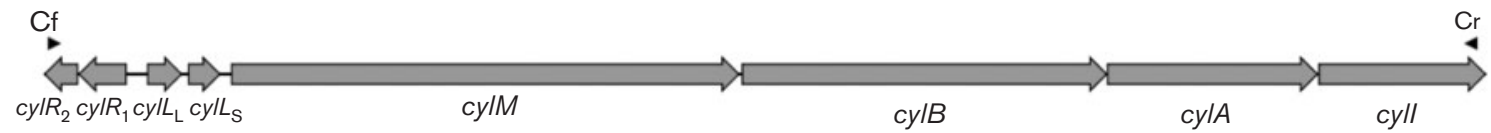

Fig. 1. Organization of the $c y /$ locus and location of the primers $\mathrm{Cf}$ and $\mathrm{Cr}$ used for the PCR. The $c y / L_{\mathrm{L}}$ and $c y / L_{S}$ genes encode precursors of two small lantibiotic-like peptides, which are subsequently modified by the $c y / M$ gene product. The $c y / B$ gene product is an ATP-binding cassette transporter that facilitates the transport of the peptides out of the cell and is involved in additional processing. The cylA gene product extracellularly processes the peptides and activates them, allowing them to combine to produce the cytolysin. The mechanism signalling the upregulation of the operon involves two regulator proteins corresponding to the cylR1 and cylR2 gene products from a divergently transcribed operon. An immunity function is present and is provided by a membrane protein encoded by the cyll gene (Clewell, 2007).

Table 1. Results from the genetic and phenotypic screening of the cytolysin system

\begin{tabular}{|lcccc|}
\hline Species & $\begin{array}{c}\text { Total no. of } \\
\text { strains }\end{array}$ & Origin (clinical/food) & PCR $^{\star}$ & Haemolysis $\dagger$ \\
\hline E. faecalis & 24 & $20 / 4$ & + & $\beta$ \\
E. faecium & 12 & $0 / 12$ & - & $\gamma$ \\
& 1 & $0 / 1$ & + & $\beta$ \\
E. durans & 6 & $2 / 4$ & - & $\gamma$ \\
E. hirae & 1 & $0 / 1$ & + & $\beta$ \\
& 7 & $0 / 7$ & - & $\gamma$ \\
\hline
\end{tabular}

* + /-, The complete cyl operon was/was not detected by PCR.

t $\gamma$ represents the absence of haemolysis; $\beta$ represents the presence of haemolysis.

not shown), making horse erythrocytes more convenient for the haemolysin assay and allowing an assay with a higher sensitivity. All 55 strains tested showed complete agreement between genotypic and phenotypic assays. This correlation was observed for the four enterococcal species tested, namely E. faecalis, E. faecium, E. durans and E. hirae.

Based on our genotypic and phenotypic screening methodology, a much higher correlation was obtained compared to any previously described screening (Shepard \& Gilmore, 2002; Creti et al., 2004; Seno et al., 2005; McBride et al., 2007; and further references therein). The PCR screening for the complete $c y l$ locus described herein gives a measure of the gene reservoir of the strain, while the phenotypic assay is still the only test that allows demonstration of active cytolysin production. As environmental factors could strongly influence gene expression (Finlay \& Falkow, 1997), it is necessary to take into account that the in vitro conditions used to test for phenotypic characters are different from those found in vivo in the human host. For these reasons, enterococci should be evaluated not only for the in vitro expression of virulence traits, but also using molecular assays for evidence of silent genes that could potentially be activated, thereby changing these bacteria into potential pathogens or augmenting their pathogenicity (Sabia et al., 2008). In the case of negative phenotype results, gene products of another strain or species could complement the lack of expression of an inactive gene. In conclusion, the incongruence previously evidenced between phenotypic and genotypic assays for the haemolysin/bacteriocin of enterococcal species is probably due to the experimental design rather than being attributable to any particular genetic phenomenon.

\section{Acknowledgements}

The authors are grateful to Fundação para a Ciência e Tecnologia through Project grant $\mathrm{PDC} / \mathrm{CVT} / 67270 / 2006$, co-financed through FEDER, and to referees for helpful suggestions. F. B. G. is grateful to Fundação para a
Ciência e Tecnologia through grant SFRH/ $\mathrm{BD} / 18757 / 2004$.

\section{F. B. Gaspar, M. T. B. Crespo and M. F. S. Lopes}

Instituto de Biologia Experimental e Tecnológica, Instituto de Tecnologia Química e Biológica, Apartado 12, 2781-901 Oeiras, Portugal

Correspondence: M. F. S. Lopes (flopes@itqb.unl.pt)

Balashova, N. V., Crosby, J. A. \& Al Ghofaily, L. (2006). Leukotoxin confers beta-haemolytic activity to Actinobacillus actinomycetemcomitans. Infect Immun 74, 2015-2021.

Bourgogne, A., Garsin, D. A., Qin, X., Singh, K. V., Sillanpaa, J., Yerrapragada, S., Ding, Y., Dugan-Rocha, S., Buhay, C. \& other authors (2008). Large scale variation in Enterococcus faecalis illustrated by the genome analysis of strain OG1RF. Genome Biol 9, R110.

Clewell, D. B. (2007). Properties of Enterococcus faecalis plasmid pAD1, a member of a widely disseminated family of pheromone-responding, conjugative, virulence elements encoding cytolysin. Plasmid 58, 205-227.

Creti, R., Imperi, M., Bertuccini, L., Fabretti, F., Orefici, G., Di Rosa, R. \& Baldassarri, L. (2004). Survey for virulence determinants among Enterococcus faecalis isolated from different sources. J Med Microbiol 53, 13-20.

Finlay, B. B. \& Falkow, S. (1997). Common themes in microbial pathogenicity revisited. Microbiol Mol Biol Rev 61, 136-169.

McBride, S. M., Fischetti, V. A., Leblanc, D. J., Moellering, R. C. \& Gilmore, M. S. (2007). Genetic diversity among Enterococcus faecalis. PLoS One 2, e582.

Park, S. Y., Kim, K. M., Lee, J. H., Seo, S. J. \& Lee, I. H. (2007). Extracellular gelatinase of Enterococcus faecalis destroys a defense system in insect hemolymph and human serum. Infect Immun 75, 1861-1869. 
Sabia, C., de Niederhäusern, S., Guerrieri, E., Messi, P., Anacarso, l., Manicardi, G. \& Bondi, M. (2008). Detection of bacteriocin production and virulence traits in vancomycin-resistant enterococci of different sources. J Appl Microbiol 104, 970-979.
Seno, Y., Kariyama, R., Mitsuhata, R., Monden, K. \& Kumon, H. (2005). Clinical implications of biofilm formation by Enterococcus faecalis in the urinary tract. Acta Med Okayama 59, 79-87.
Shepard, B. D. \& Gilmore, M. S. (2002),

Differential expression of virulence-related genes in Enterococcus faecalis in response to biological cues in serum and urine. Infect Immun 70, 4344-4352. 